\title{
Evaluering van 'n model vir Digitale Forensiese Gereedheid van die Internet van Alles
}

\author{
Outeurs: \\ Jaco-Louis Kruger \\ H Venter \\ Affiliasie: \\ Departement \\ Rekenaarwetenskap, \\ Universiteit van Pretoria, \\ Privaatsak X20, Hatfield, \\ 0028, Suid-Afrika \\ Korresponderende outeur: \\ Jaco-Louis Kruger \\ E-pos: \\ jacolouisk@gmail.com \\ Hoe om hierdie artikel aan \\ te haal: \\ Jaco-Louis Kruger, H Venter, \\ Evaluering van 'n model \\ vir Digitale Forensiese \\ Gereedheid van die \\ Internet van Alles, Suid- \\ Afrikaanse Tydskrif vir \\ Natuurwetenskap en \\ Tegnologie 39(1) (2020). \\ https://doi.org/10.36303/ \\ SATNT.2020.39.1.820 \\ Kopiereg: \\ (C) 2020. Authors. \\ Licensee: Die Suid- \\ Afrikaanse Akademie vir \\ Wetenskap en Kuns. \\ Hierdie werk is onder \\ die Creative Commons \\ Attribution License \\ gelisensieer.
}

\begin{abstract}
Evaluating a model for Digital Forensic Readiness for the Internet of Things: This contribution shows the feasibility of Digital Forensic Readiness (DFR) processes for the Internet of Things (IoT) and aims to serve as a basis for future research with regards to DFR for IoT. It is also shown that some existing IoT devices can be used for DFR for IoT. The possibility of using and expanding existing software packages to enable DFR for IoT is explored as well. This contribution aims to contribute towards the development of a new standard for DFR in IoT.
\end{abstract}

Die Internet van Alles (IvA) begin 'n groter deel van die moderne samelewing vorm. IvAtoestelle kan in verskillende omgewings gevind word, soos slimhuise, die vervoersektor, die gesondheidsektor, slimstede en selfs outomatisering in organisasies. Die toenemende afhanklikheid van IvA-toestelle verhoog die moontlikheid dat IvA-toestelle deel van voorvalle in die fisiese of kuberomgewing vorm. Tradisionele metodes vir digitale forensiese (DF) ondersoeke is nie altyd van toepassing op IvA-toestelle nie, weens die beperkte hoeveelheid verwerkingshulpbronne wat IvA-toestelle bevat. 'n Moontlike oplossing vir die uitvoering van forensiese ondersoeke op IvA-toestelle is 'n pro-aktiewe benadering bekend as Digitale Forensiese Gereedheid (DFG).

Hierdie bydrae is gebaseer op'n deeglike oorsig van die beskikbare navorsing in die akademiese wêreld om 'n duidelike proses te identifiseer wat gevolg kan word om DFG van IvA-toestelle te verseker. Vereistes vir DFG van IvA het tot die ontwikkeling van 'n model vir DFG van IvA, wat dan in 'n prototipe vir IvA-toestelle geïmplementeer word, aanleiding gegee. Daarna word die prototipe getoets en geëvalueer deur 'n simulasie van 'n slimhuisstelsel op IvAtoestelle wat pro-aktiewe DFG uitvoer, te gebruik.

Die prototipe vir DFG word getoets op grond van prestasiemetodes vir verskillende aspekte van hulpbronbeperkte toestelle. Hierdie aspekte sluit onder andere in die gebruik van die totale kapasiteit van die verwerker en beskikbare geheue op 'n IvA ontwikkelingsbord.

'n Fisiese model van 'n slimhuis word gebruik om die werking van 'n werklike scenario te illustreer waar DFG van IvA 'n rol kan speel in forensiese ondersoeke na voorvalle wat plaasgevind het. Die scenario wat in hierdie bydrae gebruik word, is waar iemand ongemagtigde toegang verkry het tot 'n slimhuis en die DFG van die slimhuis kan dan gebruik word om digitale bewyse te verskaf van die ongemagtigde toegang. Die DFG van die IvAtoestelle verseker dus dat die digitale bewyse geloofwaardig en betroubaar is in ondersoeke wat mag volg nadat 'n insident, soos ongemagtigde toegang, plaasgevind het.

Laastens toon hierdie bydrae die uitvoerbaarheid van DFG-prosesse vir die IvA en dien as basis vir toekomstige navorsing met betrekking tot DFG van IvA. Hierdie bydrae dui ook aan dat daar reeds bestaande IvA-toestelle is wat gebruik kan word om die DFG van IvA-toestelle te verbeter en te bevorder. Hierdie bydrae dui ook aan dat bestaande sagtewarestelsels aangepas en uitgebrei kan word om die DFG van IvA-toestelle te ondersteun en te bewerkstellig. Hierdie bydrae sal 'n invloed hê op toekomstige navorsing rakende die ontwikkeling van 'n standaard vir die DFG van IvA.

Nota: 'n Seleksie van referaatopsommings: Studentesimposium in die Natuurwetenskappe 31 Oktober - 1 November 2019, Universiteit van die Vrystaat. Reëlingskomitee: Prof Rudi Pretorius (Departement Geografie, Universiteit van Suid-Afrika); Dr Hertzog Bisset (Suid-Afrikaanse Kernenergie-korporasie; Dr Ernie Langner (Departement Chemie, Universiteit van die Vrystaat) en Dr Wynand Nel (Departement Rekenaarwetenskap en Informatika, Universiteit van die Vrystaat). 